\title{
KOMUNIKASI PRIMER DAN SEKUNDER CITY BRANDING
}

\author{
PRIMARY AND SECONDARY CITY BRANDING \\ M R A Siregar1a, R Jayawinangun1a \\ 1 Program Studi Ilmu Komunikasi , Fakultas Ilmu Sosial Dan Ilmu Budaya, Universitas Pakuan PO BOX \\ 452 Kota Bogor. \\ a Korespondensi: Mariana Rista Ananda Siregar, E-mail: ristasiregar@yahoo.com \\ (Diterima: 18-12-2018; Ditelaah: 19-12-2018; Disetujui: 08-01-2019)
}

\begin{abstract}
Understanding public character is important to implement the city branding communication in social media where students as one of the potential group who using it. This research aims to show the character and use of the social media which is mostly used by students as medium to find information needed. The method used in this research is quantitative method through descriptive statistical analysis (frequency and percentage) to analyze the independent variables by conducting score track analysis to analyze the assessment this research. This research uses simple random sampling through Slovin formula. The primary form of communication strategies in the form of city landscape revitalization of historic sites in Bogor which is rated good. While the open green-space is generally measured good enough. On the secondary stage of communication, social media is mostly used as a reference in to acquire information among the students in Bogor Municapility which specifically done through instagram, facebook, and twitter. Instagram is the most widely used, second to that is youtube then followed by facebook. The characteristic of students who use social media in Bogor City is dominated by students by 52 percent in comparison to 48 percent of others respondents. In the group of 18-26 years old, the age-group with the most user are the following (in order): aged 22 years (36\%), 21 years of age (28\%), 20 years (18\%), and the rest are less than 20 years. Furthermore, as much of $62.8 \%$ respondents live in the city of Bogor.
\end{abstract}

Keywords: Communication strategy, compare information, mass media audiences

\section{ABSTRAK}

Untuk mengefektifkan pelaksanaan strategi komunikasi city branding di media sosial, pemerintah Kota Bogor perlu memahami karakter publiknya (komunikan), salah satu publiknya adalah mahasiswa. Mahasiswa merupakan salah satu publik potensial pesan komunikasi city branding suatu daerah. Penelitian ini bertujuan mengenali karakter dan pemanfaatan media sosial mereka dalam penelusuran informasi publik daerahnya dan media sosial mana yang paling sering digunakan mahasiswa. Metode yang digunakan dalam penelitian ini adalah metode deskripsi kuantitatif yang terdiri dari analisis statistik deskriptif (frekuensi dan persentase) digunakan untuk menganalisis deskripsi peubah peubah-peubah karakteristik responden, dan analisis rataan skor digunakan untuk menganalisis penilaian dari komunikasi kota. Pengambilan sampel penelitian dilakukan dengan cara quota sampling menggunakan rumus Slovin. Hasil penelitian menunjukkan mahasiswa di Kota Bogor memiliki tiga media sosial instagram, facebook, twitter. Dilihat dari keaktifan penggunaan instagram, youtube, dan Facebook. Karakteristik mahasiswa yang menggunakan media sosial di Kota Bogor dalam penelitian ini di media massa didominasi oleh mahasiswa dengan perbandingan 52 persen dengan 48 persen responden mahasiswi. Di rentang usia 18-26 tahun, usia mereka tiga terbanyak adalah berusia 22 tahun, usia 21 tahun, usia 20 tahun sebanyak, sisanya kurang 
dari umur 20 tahun, dan sebanyak 62,8 persen bertempat tinggal di Kota Bogor. Komunikasi primer yang ditemukan berupa strategi lanskap kota dalam bentuk revitalisasi situs bersejarah di Kota Bogor dinilai baik, sedangkan ruang terbuka hijau secara umum dinilai cukup baik. Pada tahapan komunikasi sekunder, media sosial paling sering menjadi rujukan mencari informasi Kota Bogor di kalangan mahasiswa terutama adalah akun instagram, facebook, dan twitter Pemerintah Kota Bogor.

Kata Kunci : City branding, media sosial, strategi komunikasi

Siregar, M, R, A,. \& Jayawinangun, R. (2019). Komunikasi Primer dan Sekunder City Branding. Jurnal Sosial Humaniora, 10(2), 11-18.

\section{PENDAHULUAN}

Iklim globalisasi telah mendorong kota-kota di seluruh dunia untuk berkompetisi dalam hal menarik pengunjung dan investor. Atmosfer kompetisi tersebut telah membuat pemerintah daerah di berbagai penjuru dunia mulai memacu pembangunan dan pemasaran daerahnya melalui gagasan pengembangan citra (image/brand). Tantangan globalisasi tersebut dijawab berbagai daerah dengan melakukan upaya menonjolkan karakteristik khusus yang mereka miliki, salah satunya dengan mengusung konsep city branding. Dahulu branding dikenal untuk produk barang dan jasa kini mulai banyak dipakai untuk memasarkan sebuah wilayah baik level daerah maupun negara.

Mengacu pendapat (Simon Anholt, 2007) city branding sebagai manajemen citra suatu destinasi melalui inovasi strategis serta kordinasi ekonomi, komersial, sosial, kultural dan peraturan pemerintah. Melihat pergeseran masif terkait fenomena manajemen citra kota tersebut berimplikasi pada efektivitas implementasi perencanaan komunikasi city branding yang matang dalam membangun brand dan positioning yang baik agar dapat diterima oleh khalayak luas sebagai target pasar. Pelibatan dan pemanfaatan media massa seperti media cetak dan elektronik ikut menentukan keberhasilan dalam program city branding di beberapa kota besar di Indonesia. Jika melihat kerangka teori yang dibangun oleh (Kavaratzis, 2004) dalam memahami merek kota dan pengelolaannya terkait kajian literaturnya mengenai pemasaran kota dan merek perusahaan. Merek kota dianggap dapat meningkatkan capaian pembangunan ekonomi sekaligus sebagai identitas bagi penduduk kota tersebut. Relevansi dari membangun merek kota akan memperkuat daya saing sumberdaya yang ada, meningkatkan investasi, dan wisata. Efek potensial bagi penduduk setempat dan yang didapat melalui merek suatu kota dan juga bermanfaat untuk mengatasi masalah-masalah sosial yang mendesak. Karavitz mengungkapkan bahwa dalam rangka membangun citra kota dikomunikasikan melalui tiga jenis komunikasi, yaitu primer, sekunder dan tersier.

Berdasarkan kerangka teoretis yang dibangun Kavaratzis yang memahami bahwa proses pengelolaan citra suatu kota dikomunikasikan dalam bentuk komunikasi primer, sekunder, dan tersier. Penelitian ini hanya dibatasi untuk mengetahui bagaimana bentuk komunikasi yang dilakukan pemerintah Kota Bogor dalam bentuk komunikasi primer dan sekunder. Pembentukkan identitas suatu kota pada tataran komunikasi primer di beberapa kota dikelola keunikan, kebudayaan, event, dan potensi daerah di pasar global sebagai salah satu upaya mengomunikasikan identitas kotanya.

Sosial media telah memengaruhi branding tempat (place branding) dan diadopsi dengan baik (Braun et al. 2013 ; Yan 2011 ) dalam (Sevin, 2016). Media sosial sebagai medium yang dianggap relatif berbiaya rendah telah menjadi pilihan medium komunikasi city branding pemerintah setempat dibandingkan menggunakan media promosi konvensional. Selain keuntugan finansial, Sevin melihat media sosial menjadi medium beriklan yang menguntungkan. Media sosial juga memungkinkan pelaku. Media sosial juga memungkinkan kerja dengan berbagai bentuk medium konten, seperti video dan audio, secara bersamaan dan mendorong inovasi di berbagai proyek.

Pada kasus branding tempat, media sosial memunculkan peluang bagi komunikasi kota di tingkat proses komunikasi sekunder dan komunikasi tersier (Kavaratzis, 2004)dalam (Sevin, 2016). Komunikasi digital telah menempatkan kampanye branding pada target khalayak dimana mereka berada. Media sosial juga dapat memunculkan reputasi dan brand 
daerah yang dipengaruhi melalui komunikasi dari mulut ke mulut di media sosial dalam jaringan. Keterlibatan berbagai pemangku kepentingan (stakeholder), termasuk target khalayak dan interaksi antar mereka merupakan salah satu bentuk kontribusi mempromosikan daerah. Media sosial juga dapat memfasilitasi bentuk kontribusi dan interaksi komunikasi kota. Twitter contohnya, memungkinkan penggunanya berkomunikasi secara langsung dengan pengguna twitter lainnya maupun dengan grupnya sendiri. Medium ini juga dapat diamati, diteliti, dan dapat dievaluasi dalam proses branding daerah serta dapat sesegera mungkin membentuk persepsi merek/imaji, termasuk mengubah perilaku individu.

Penelitian ini bertujuan melihat karakter publik kota Bogor dan pemanfaatan media sosialnya sebagai publik potensial yang tingkat penetrasi internetnya cukup tinggi. Masalah penelitian ini dirumuskan sebagai berikut: Bagaimana karakteristik mahasiswa kota Bogor? Bagaimana komunikasi primer Kota Bogor? Bagaiman komunikasi sekunder Kota Bogor?

\section{MATERI DAN METODE}

Penelitian didesain sebagai penelitian kuantitatif yang mengkombinasikan antara penelitian menerangkan (explanatory research) dengan penelitian deskriptif (descriptive research) dan pengujian dari hipotesis. Metode penelitian ini menggunakan metode survei dengan pendekatan deskriptif. (Singarimbun dan Effendi, 2010) menjelaskan bahwa penelitian deskriptif adalah penelitian yang memberikan gambaran yang lebih mendalam tentang gejala-gejala sosial tertentu atau aspek kehidupan tertentu pada masyarakat tertentu yang diteliti.

Populasi penelitian ini adalah mahasiswa beberapa Universitas di Kota Bogor yang domisili di luar Kota Bogor dan pengikut (follower) akun resmi Facebook dan Instagram Pemkot Bogor. Menurut data Badan Pusat Statistik Kota Bogor dalam Angka, jumlah keseluruhan mahasiswa dari lima Universitas di Kota Bogor (Universitas Ibnu Khaldun, Universitas Pakuan, Universitas Nusa Bangsa, Universitas Djuanda dan Institut Pertanian Bogor) sebanyak 45.763 mahasiswa/i. Pengambilan sampel dengan cara quota sampling dimana pengambilan sampel tersebar di tempat populasi berada. Penarikan sampel menggunakan rumus Slovin Berikut fomula untuk menghitung sampel penelitian dengan rumus Slovin:

$$
n=\frac{\mathrm{N}}{1+\mathrm{N}(\mathrm{e})^{2}}
$$

Keterangan : $\mathrm{n}=$ Ukuran Sempel $; \mathrm{N}=$ Ukuran

Populasi; e : Persen kelonggaran ketidaktelitian karena kesalahan pengambilan sempel yang masih dapat ditolerir atau diinginkan

Data yang dikumpulkan di dalam penelitian adalah data primer dan data sekunder. Data primer diambil melalui kuesioner dan wawancara dari peubah yang diteliti berupa komunikasi city branding Kota Bogor dan media sosial. Data sekunder yang dikumpulkan berkaitan dengan keadaan umum dan data potensi aktual mengenai kondisi geografis yang dapat diperoleh dari pihak-pihak atau lembaga terkait topik penelitian. Instrumen pada penelitian ini adalah pertanyaan dan pernyataan dalam bentuk kuesioner yang dibangun menjadi tiga bagian yaitu perencanaan komunikasi city branding Kota Bogor dan pemanfaatan media sosial Facebook dan Instagram.

Pengumpulan data dilakukan untuk memperoleh informasi yang dibutuhkan dalam rangka mencapai tujuan penelitian. Pengumpulan data dilakukan dengan beberapa langkah, yaitu: Survei pendahuluan yaitu tahapan awal dengan melakukan pengamatan dan penelitian pendahuluan guna mengumpulkan data-data untuk memperkuat atau mempertajam permasalahan yang terjadi di lapangan sehingga peneliti yakin penelitian ini perlu dan dapat dilaksanakan; Proses pengumpulan data kuantitatif dengan metode survei yang dilakukan dengan intrumen berupa kuesioner. Data primer ini diperoleh langsung dari hasil wawancara terstruktur dengan menggunakan kuesioner yang telah diuji validitas dan reliabilitasnya.

Uji validitas dan reliabilitas maka akan dilakukan uji coba terhadap 30 orang sampel. (Muljono, 2012) menjelaskan, validitas adalah sejauh mana ketepatan dan kecermatan suatu alat ukur dalam melakukan fungsi ukurnya. Suatu instrumen pengukuran dikatakan memiliki validitas yang tinggi apabila alat ukur tersebut menjalankan fungsi ukurnya atau memberikan hasil ukur yang sesuai dengan maksud dilakukannya pengukuran tersebut. Validitas instrumen diperoleh dengan cara menyesuaikan daftar pertanyaan dengan judul penelitian dan memperhatikan saran-saran para ahli dan teoriteori dalam pustaka. Penelitian ini, uji validitas yang digunakan adalah korelasi produk momen (product moment correlation) Pearson. Dari hasil 
uji validitas diketahui semua pernyataan dinyatakan valid, dengan nilai korelasi product momen berkisar 0,374-0,878.

Reliabilitas menurut (Singarimbun dan Effendi, 2010) adalah sejauh mana suatu alat pengukur dapat dipercaya atau dapat diandalkan. (Muljono, 2012) menjelaskan, reliabilitas instrumentasi berarti sejauh mana hasil suatu pengukuran dapat dipercaya. Reliabilitas instrumen penelitian yang digunakan adalah koefisien reliabilitas Alpha Cronbach. Berikut rumus untuk menghitung koefisien reliabilitas alpha Cronbach.

$$
\alpha=\left(\frac{K}{K-1}\right)\left(\frac{S r^{2}-\Sigma_{s i}}{S x^{2}}\right)
$$

Keterangan : $\alpha=$ Koefisien reliabilitas Alpha Cronbach; $\mathrm{K}=$ Jumlah item pertanyaan yang diuji; $\sum$ si 2 = Jumlah Varians Skor Tes (seluruh item $\mathrm{K}$ ).

Tingkat reliabilitas instrumen ditentukan berdasarkan skala Alpha Cronbach 0-1. Nilai hasil uji reliabilitas dikelompokkan sebagai berikut (a) dikatakan kurang reliabel, jika nilai Alpha Cronbach 0.00-0.20, (b) dikatakan agak reliabel, nilai Alpha Cronbach > 0.2-0.40, (c) dikatakan cukup reliabel, jika nilai Alpha Cronbach $>0.4-$ 0.60, (d) dikatakan reliabel, jika nilai Alpha Cronbach > 0.6-0.80, dan (e) dikatakan sangat reliabel, jika nilai Alpha Cronbach lebih dari 0.81 . Dari hasil uji reliabilitas diketahui nilai alpha cronbach untuk variabel komunikasi kota sebesar 0,919 dan city branding sebesar 0,929 sehingga dapat dikatakan sangat reliabel.

Analisis data dilakukan setelah menabulasikan data dilakukan analisis dan interpretasi hasil analisis data dengan tiga analisis: Analisis statistik deskriptif (frekuensi dan persentase) digunakan untuk menganalisis deskripsi peubah peubah-peubah penelitian; Analisis rataan skor digunakan untuk menganalisis penilaian dari perubah penelitian.

Frekuensi dan presentase dalam penelitian ini digunakan untuk menganalisis karakter. Mahasiswa sebagai responden pengguna media sosial dan target komunikasi city branding Kota Bogor. Analisis rataan skor digunakan untuk menganalisis pemanfaatan media sosial mahasiswa dalam memahami komunikasi primer dan sekunder kotanya.

\section{HASIL DAN PEMBAHASAN}

Berdasarkan hasil pengumpulan data, telah dikumpulkan data sebanyak 121 responden dari total 12 responden yang ditargetkan pada penelitian ini yang terdiri dari empat perguruan tinggi dengan jumlah mahasiswa terbanyak di Kota Bogor, yaitu Universitas Pakuan (UNPAK), Institut Pertanian Bogor (IPB), Universitas Ibn Khaldun (UIKA) dan Universitas Nusa Bangsa (UNB). Adapun rincian data yang terkumpul dan kekurangan data dapat dilihat pada

Tabel 1. Rekap Data Populasi dan Responden.

\begin{tabular}{lccc}
\hline Universitas & EResponden & Target Sampel & E Sampel Terkumpul \\
\hline UNPAK & 13502 & 35 & 35 \\
PB & 24888 & 50 & 50 \\
UIKA & 6036 & 20 & 20 \\
UNB & 1337 & 15 & 16 \\
\hline Total & 45763 & 120 & 121 \\
\hline
\end{tabular}

Sumber : Kota Bogor dalam Angka 2017 dan olahan.

Responden dalam penelitian ini diambil berdasarkan kriteria yang telah ditetapkan oleh peneliti yaitu mahasiswa dari beberapa Perguruan Tinggi di Kota Bogor dan sudah tinggal di Kota Bogor minimal 3 tahun. Karakteristik umum responden dalam penelitian ini terdiri dari beberapa kategori, yaitu jenis kelamin, usia, semester dan asal tempat tinggal.

Karakteristik responden berdasarkan jenis kelamin terdiri atas laki-laki $52 \%$ dan perempuan $48 \%$. Data ini juga relevan dengan hasil survei pengguna internet di Indonesia 51,4 persen 262 juta penduduk Indonesia adalah berjenis kelamin laki-laki Jumlah responden berdasarkan jenis kelamin ini diharapkan dapat mewakili persepsi berdasarkan jenis kelamin. Sebaran persentase responden berdasarkan jenis kelamin dapat dilihat pada,

\section{Gambar 1. Sebaran persentase responden berdasarkan kelamin.}

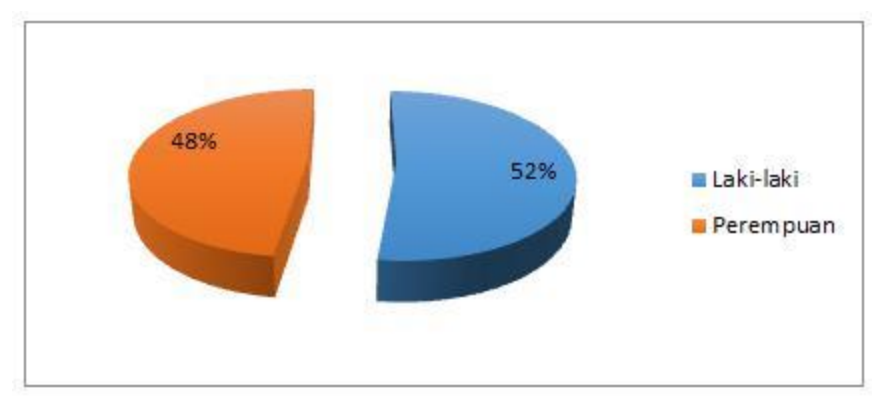

Berdasarkan Gambar 2, dapat diketahui responden kelompok usia 20-22 tahun 
mendominasi untuk sebaran responden pada penelitian ini dengan persentase sebesar $82 \%$.

Pada Kelompok usia ini mahasiswa sedang pada masa aktif menjalankan organisasi di kampus, sehingga dapat dengan mudah untuk ditemui. Hasil survei penetrasi internet Asosiasi Penyelenggara Jasa Internet Indonesia juga menunjukkan bahwa penetrasi pengguna internet di Indonesia di rentang umur 19-34 tahun sebesar $74,23 \%$ menempati posisi kedua terbanyak setelah pengguna internet di rentang umur 13-18 tahun sebesar 75,50\% (Asosiasi Penyelenggara Jasa Internet Indonesia - APJII, 2017). Sebaran persentase responden berdasarkan usia dapat dilihat pada,

Gambar 2. Sebaran persentase responden berdasarkan usia.

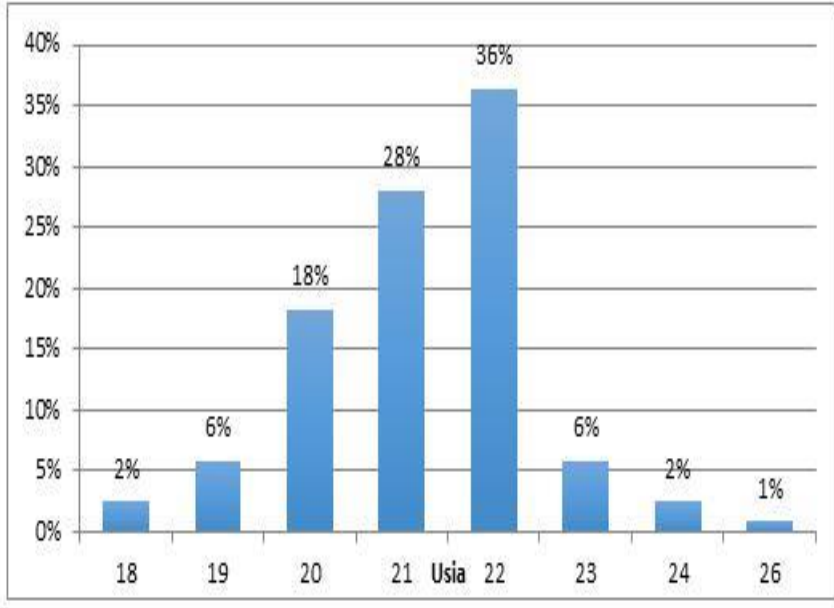

Berdasarkan Gambar 3, dapat diketahui sebagian besar responden adalah semester 8 dengan persentase sebesar 56\%, diikuti semester 4 sebesar 22\%. Pada Kelompok semester ini diharapkan mahasiswa sudah mengerti tentang fenomena yang terjadi disekitarnya sehingga dapat menilai objektif tentang objek penelitian. Selain itu jika ada mahasiswa dari luar Bogor yang menjadi responden penelitian ini pengalaman fisik dan psikis kota Bogornya minimal sudah terpapar selama 3 tahun. Sebaran persentase responden berdasarkan usia dapat dilihat pada,
Gambar 3. Sebaran persentase responden berdasarkan semester.

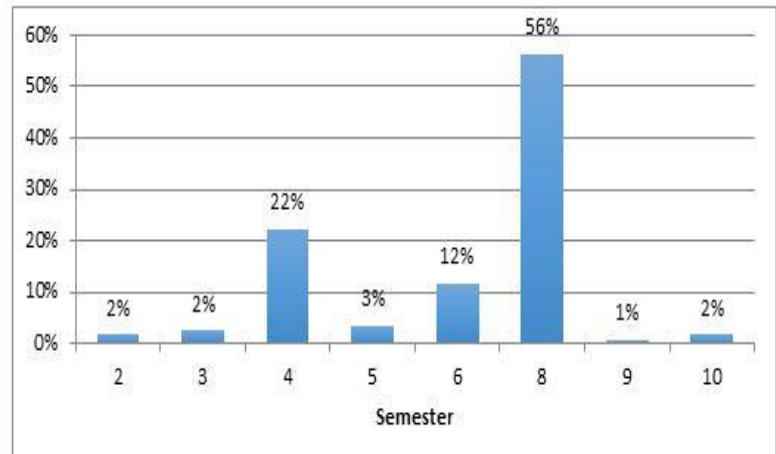

Berdasarkan Gambar 4, dapat diketahui sebagian besar responden berasal dari Bogor dengan persentase sebesar 62,8\%, sedangkan sisanya berasal dari luar Bogor dengan persentase sebesar 37,2\%. Responden asal Bogor lebih banyak daripada mahasiswa luar Bogor dikarenakan memang lokasi penelitian dilakukan di Bogor sehingga lebih banyak mahasiswa yang berdomisili di sekitar Bogor yang sering ditemui saat penelitian berlangsung. Sebaran persentase responden berdasarkan asal tempat tinggal dapat dilihat pada,

Gambar 4. Sebaran persentase responden berdasarkan asal tempat tinggal.

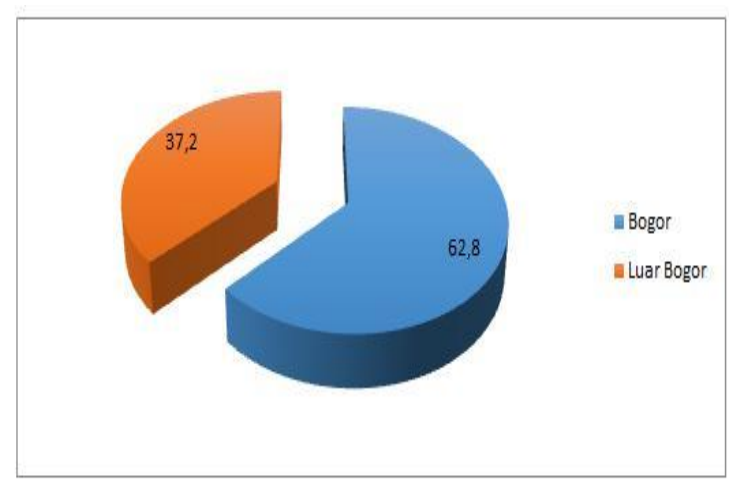

Orang muda dan internet khususnya media sosial tidak dapat dipisahkan, hal ini sesuai dengan hasil survei APJII yang menyebutkan bahwa generasi muda dalam rentang usia 19-34 tahun memiliki angka penetrasi hampir 80 persen pengguna internet di Indonesia (Asosiasi Penyelenggara Jasa Internet Indonesia - APJII, 2017). Angka tersebut relatif tinggi ketimbang penduduk kelompok usia lainnya. Media sosial adalah layanan yang diakses kedua terbanyak setelah chatting dengan persentase sebesar $89,35 \%$.

Terkait komunikasi primer kota (Kavaratzis, 2004) yang memaparkan city branding dimaknai sebagai sarana untuk mencapai keunggulan 
kompetitif suatu kawasan dalam rangka meningkatkan investasi dari pariwisata dan juga sebagai pencapaian pembangunan masyarakat. City branding umumnya memfokuskan pada pengelolaan citra, tepatnya apa dan bagaimana citra itu akan dibentuk serta aspek komunikasi yang dilakukan dalam proses pengelolaan citra (Kavaratzis, 2004). Alasan yang paling umum dari penerapan strategi merek dalam komunikasi citra kota adalah untuk mendorong pertumbuhan Tabel 2. Komunikasi Primer Kota Bogor

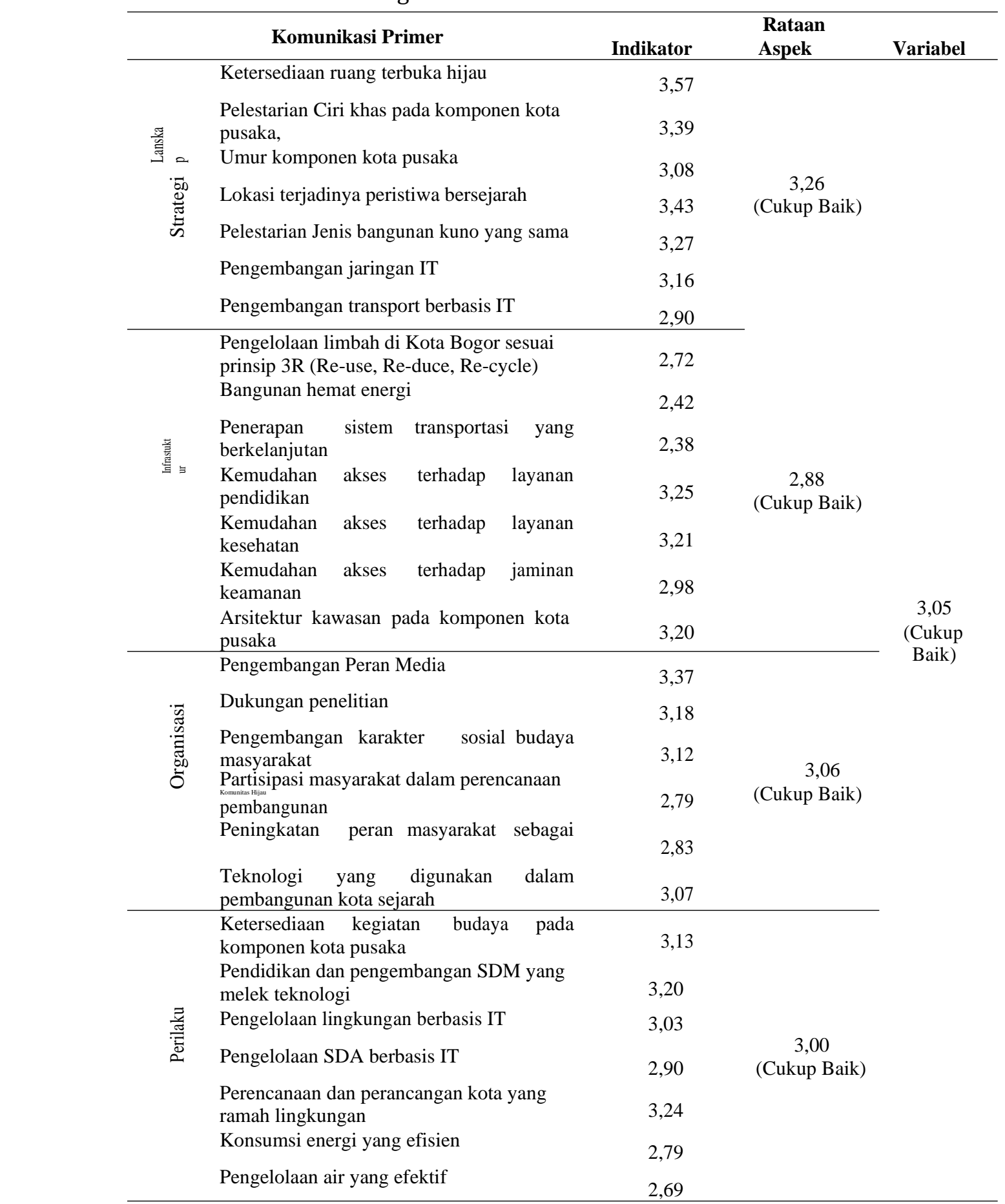

ekonomi kota atau daerah, melalui pendekatan komunikasi primer (spasial dan non-spasial) Tabel 1 menunjukkan bahwa komunikasi primer berupa strategi lanskap kota yang sudah dilakukan dan secara umum dinilai cukup baik. Ketersediaan ruang terbuka hijau dan lokasi terjadinya peristiwa bersejarah, dan pelestarian jenis bangunan kuno yang sama dinilai responden dinilai baik.
Untuk komponen komunikasi kota pada aspek infrastruktur secara umun dinilai tidak baik dari tujuh indikator. Pada aspek struktur organisasi komunikasi kota yang sudah dilakukan kota
Bogor dari enam pernyataan indikator secara umum dinilai cukup baik. Responden menilai pernyataan indikator aspek perilaku secara umum dinilai sudah cukup baik. 
Berdasarkan kepemilikan dan keaktifan bermedia sosial perilaku penggunaan media sosial sebagai medium komunikasi sekunder kota dapat memudahkan penyusunan strategi city branding. Berdasarkan hasil data di lapangan diketahui bahwa aplikasi yang paling banyak dimiliki mahasiswa adalah instagram, diikuti Facebook, Twitter, Youtube dan Blog. Dilihat berdasarkan keaktifan penggunaanya, diketahui bahwa instagram adalah aplikasi yang paling aktif digunakan, diikuti Youtube dan Facebook. Hasil jawaban pertanyaan terbuka menunjukkan responden banyak mengetahui info mengenai Kota Bogor melalui media sosial Instagram, terutama akun Instagaram, twitter dan situs resmi Pemerintah Kota Bogor. Sebaran persentase responden berdasarkan kepemilikan dan keaktifan media sosial dapat dilihat pada, Gambar 5.Sebaran persentase responden berdasarkan kepemilikan dan keaktifan media sosial.

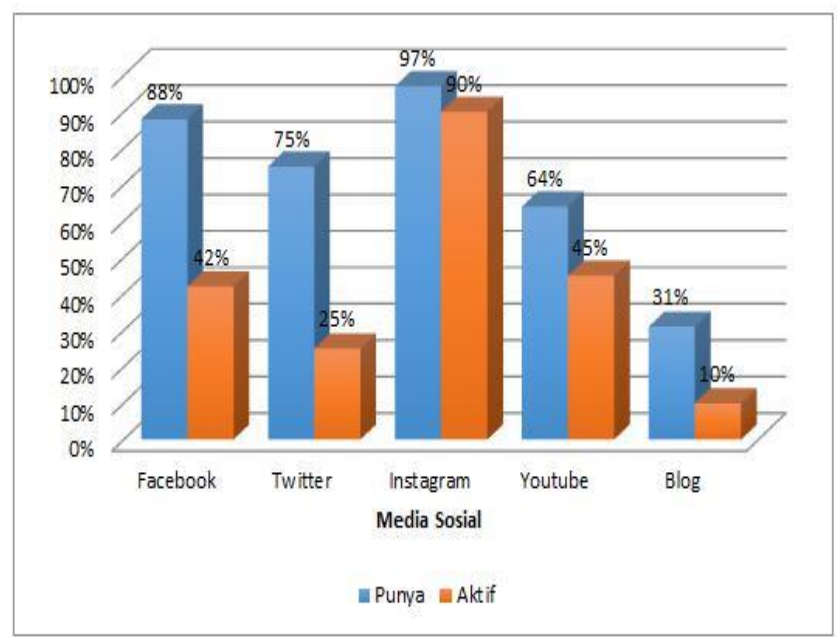

Gambar 5 menunjukkan bahwa keaktifan penggunaan akun Youtube sebesar (45\%) dari 64 persen kepemilikan media lebih tinggi dibanding Facebook dengan nilai kepemilikan sebesar (88\%) dan tingkat keaktifan penggunaannya hanya sebesar (42\%). Data ini menunjukkan akun Youtube di kalangan mahasiswa cukup banyak digunakan walaupun jumlah kepemilikannya lebih rendah dari akun facebook. Media audio visual berbasis internet ini bisa menjadi salah satu media sosial tambahan sebagai media komunikasi city branding. (Kusniadji, 2016) dalam penelitiannya juga mengungkapkan bahwa dalam menyusun strategi komunikasi pemasaran ke depan perlu mempertimbangkan kemajuan Teknologi Informasi Dan Komunikasi seperti penggunaan Facebook, Twitter, Email dan lain-lain untuk mendukung aktivitas komunikasi pemasaran suatu institusi

\section{KESIMPULAN}

Komunikasi digital telah menempatkan kampanye branding pada target khalayak dimana mereka berada. Keterlibatan mahasiswa sebagai salah satu pemangku kepentingan Kota Bogor menjadi salah satu target khalayak potensial dimana tingkat interaksi antar mereka di media sosial dapat berkontribusi dalam mempromosikan daerah. Media sosial juga dapat memfasilitasi bentuk kontribusi dan interaksi komunikasi kota. Dengan demikian sebagai langkah awal penyusunan strategi komunikasi kotanya, Pemerintah Kota Bogor perlu mengetahui karakteristik publiknya dalam menggunakan dan memanfaatkan media sosial sebagai medium komunikasi target khalayaknya. Hal serupa juga dikemukakan dalam penelitian (Rusdi, 2018), bahwa melalui internet, identitas suatu kota dapat dikenalkan kepada khalayak luas, bahkan hingga mancanegara.

Karakateristik mahasiswa di Kota Bogor paling banyak berada di usia di rentang umur 20-22 tahun, dan sebagian besar tinggal di Kota Bogor. Artinya mereka dianggap cukup lama menjalani komunikasi kotanya dan dapat mempersepsi kotannya cukup baik.

Komunikasi lanskap kota sebagai salah satu bentuk komunikasi primer yang sudah dilakukan pemerintah Kota Bogor dan secara umum dinilai cukup baik adalah berupa penataan ruang terbuka hijau yang diwujudkan dalam bentuk pembangunan taman kota. Memaknai kota Bogor sebagai salah satu kota tempat terjadinya peristiwa bersejarah dengan melakukan revitalisasi situs bersejarah dan pelestarian jenis bangunan kuno yang dinilai responden dinilai baik kegiatan komunikasi primernya. Pada aspek infrastruktur, mahasiswa menilai tidak tidak baik dari tujuh indikator. Responden menilai pernyataan indikator aspek perilaku secara umum dinilai sudah cukup baik.

Pada tahapan komunikasi sekunder, yang dirasakan mahasiswa sebagai salah satu publik komunikasi kota. Mereka banyak memiliki akun, aktif menggunakan, dan mendapatkan pengetahuan mengenai kotanya melalui akun instagram, facebook dan twitter pemerintah kota Bogor. Namun demikian jika dilihat pada tingkat keaktifan penggunaan media sosialnya, YouTube menjadi salah satu media yang penggunaanya cukup aktif di kalangan mahasiswa. Artinya 
selain ketiga media sosial yang telah disebutkan di awal, media ini bisa menjadi media alternatif dalam mengoptimalkan komunikasi city branding Kota Bogor.

\section{DAFTAR PUSTAKA}

Anholt, S. 2007. Competitive Identity: The New Brand Management for Nations, Cities, And Regions. New York: Palgrave Macmillan.

Asosiasi Penyelenggara Jasa Internet Indonesia APJII. (2017). Penetrasi \& Perilaku Pengguna Internet Indonesia 2017.

Badan Pusat Statistik Kota Bogor. 2017. Kota Bogor Dalam Angka 2017. Bogor : Badan Pusat Statistik

Kavaratzis, M. (2004). From city marketing to city branding: Towards a theoretical framework for developing city brands. Place Branding, 1(1), 58-73. https://doi.org/10.1057/palgrave.pb. 5990005
Muljono P. 2012. Metode Penelitian Sosial. Bogor: IPB Press.

Sevin, E. (2016). Social Media and Local Governments, (October). https://doi.org/10.1007/978-3-31917722-9

Rusdi, Farid dan Sukendro, Gregorius Genep. (2018). Analisis Industri Kreatif Dalam Memanfaatkan Identitas Kota Melalui Media Baru. Jurnal Komunikasi Untar, Vol.10 No. 1. E.ISSN:2528-2727.

Kusniadji, Suherman. (2016). Strategi Komunikasi Pemasaran dalam Kegiatan Pemasaran Produk Consumer Goods (Studi Kasus pada PT Expand Berlian Mulia Di Semarang). Jurnal Komunikasi Untar, Vol.8 No. 1. E.ISSN:2528-2727. 